\title{
HEPATITIS C IN CHILDREN;
}

Its management

Dr. Abdul Rehman.

ABSTRACT..... The knowledge of the hepatitis $\mathrm{C}$ management in children is scanty but rapidly growing. This review will discuss the update in the management of the disease in children. Abbreviations: Hepatitis C virus (HCV); International unit (IU); Polymerase chain reaction (PCR); Sustained virological response (SVR); Rapid virological response (RVR); Early virological response (EVR); End-oftreatment response (ETR)

Key words: Sustained virological response; Peginterferon alfa-2a; Peginterferon alfa-2b; Ribavirin; Chronic hepatitis C; Management; Adverse effects; Liver biopsy.

Article Citation

Rehman A. Hepatitis C in children; Its management. Professional Med J 2013;20(3): 322-331.

\section{INTRODUCTION}

Hepatitis C virus (HCV) infection is a major global health problem and about 70-100,000 children are infected with HCV. Although HCV can lead to liver transplantation and death during childhood but the disease acquired during childhood have slow progression ${ }^{1}$. Approximately $2 \%$ cases may experience rapid histological progression to liver cirrhosis during early childhood ${ }^{2}$.

\section{TO TREAT OR NOT TO TREAT}

Treatment is avoided in acute hepatitis as there are $25-50 \%$ chances of spontaneous resolution and fulminant hepatic failure from HCV has not been described in children ${ }^{3}$.

The pharmacological efficacy of peginterferon and ribavirin seems to be proven but there are different opinions about 'who, when and how to treat children infected ${ }^{\prime 4}$. Robinson et al reviewed the literature and concluded that there is no clear indication for antiviral therapy in the majority of children with HCV infection ${ }^{1}$. The arguments in favour of treatment of chronic hepatitis (detectable serum HCV RNA for longer than 6 months) are that it prevents disease progression, removes social stigma, reduction of long-term morbidity, cost-effectiveness on a drug-per-weight basis, and elimination of the virus before life events or behaviors that promote transmission (pregnancy and delivery, or intravenous drug use $)^{5}$. Overall the quality of life and psychosocial functioning are not deteriorated by the treatment of children with $\mathrm{HCV}^{6}$. The arguments against the treatment are that HCV is mild in most children and the morbidity is delayed, subjecting them to up to 1 year of subcutaneous injections with possible adverse drug effects is as yet unwarranted, and is costly for families ${ }^{5}$. For the majority of HCV-infected children showing minimal fibrosis on biopsy and no active hepatitis, there is no data to support immediate therapy ${ }^{5}$. Children with hepatitis C who demonstrate persistently elevated serum aminotransferases or those with progressive disease (i.e. fibrosis on liver histology) should be considered for treatment ${ }^{7}$.

\section{AIM OF TREATMENT AND TERMINOLOGY}

The aim of therapy is to achieve negative conversion of HCV viremia to a level below the detection limit of the qualitative polymerase chain reaction (PCR) technique employed (10-50 IU/ml). Once negativity has been achieved, treatment must continue long enough to ensure eradication of the infection from the liver ${ }^{8}$. Several types of virological responses are used to assess efficacy, labeled according to their timing relative to treatment. These are tested sensitive PCR based quantitative assay which may detect HCV RNA 
as low as $10 \mathrm{IU} / \mathrm{ml}$. The definitions of these virological responses are based on the recommendations of American Association for the Study of Liver Diseases $2009^{9}$.

\section{RAPID VIROLOGICAL RESPONSE (RVR)}

HCV RNA is negative in the serum at treatment week 4.

\section{EARLY VIROLOGICAL RESPONSE (EVR)}

$\geqslant 2 \log$ reduction in HCV RNA level in the serum but not negative as compared to the baseline HCV RNA level (partial EVR) or HCV RNA level negative in the serum at treatment week 12 (complete EVR).

\section{END-OF-TREATMENT RESPONSE (ETR)}

HCV RNA negative in the serum at the end of treatment (which may be either 24 or 48 weeks).

\section{SUSTAINED VIROLOGICAL RESPONSE (SVR)}

HCV RNA negative in the serum 24 weeks after cessation of treatment.

\section{BREAKTHROUGH}

Reappearance of HCV RNA in the serum while still on therapy.

\section{RELAPSE}

Reappearance of HCV RNA in serum after therapy is discontinued.

\section{NONRESPONDER}

May be "null responder" or "partial responder (Failure to clear HCV RNA from serum after 24 weeks of therapy.

\section{DRUG THERAPY}

The peginterferon alfa with or without ribavirin, like in adults, has been used in the treatment of chronic hepatitis $C$ in children. The studies ${ }^{10,11,12,13,14,15}$ in which peginterferon $\alpha-2 b$ was used in children are shown in table-I while studies in which peginterferon $\alpha$-2a were used $^{16,17,18}$ are shown in table-II. These studies used peginterferon $\alpha-2 b$ in a dose of $1-1.5 \mathrm{mg} / \mathrm{kg} /$ week and ribavirin in a dose of $15 \mathrm{mg} / \mathrm{kg} /$ day except in the study by Baker et al $2007^{11}$ who used ribavirin $800 \mathrm{mg} /$ day as the ages of patients were 14-17 years. The dose of peginterferon $\alpha-2 a$ used in these studies was 100 $\mathrm{ug} / \mathrm{m} 2$ once weekly while ribavirin, if used, in the same doses as with peginterferon $a-2 b$. Schwarz et al $2006^{16}$ used only peginterferon $\alpha-2 a$ while Schwarz et al $2011^{17}$ compared the two group, one with ribavirin and other without ribavirin and found that combination therapy was better than monotherapy. Recent studies in adults ${ }^{19,20,21}$ have shown the superiority of $\alpha$-2a with equal or better safety over $\alpha-2 b$ but there are no randomized studies available in children to compare these two peginterferons in children. It is not possible to infer which peginterferon is better in children. The Infectious Diseases Society of America and the American College of Gastroenterology 2009 recommended the use of peginterferon alfa-2b with ribavirin for hepatitis $C$ in children in a dose of 60 $\mathrm{ug} / \mathrm{m} 2$ weekly given subcutaneously in combination with ribavirin $15 \mathrm{mg} / \mathrm{kg}$ daily in 2 divided doses ${ }^{9}$ but these recommendations might be reconsidered to include peginterferon $\alpha-2 a$ in combination with ribavirin for the treatment as well.

Different HCV genotypes exhibit different sensitivities to treatment both in children and adults. The SVR rates are higher in children with genotype 2 or 3 as compared to genotype 1 and $4^{11,12,13,14,17,18}$. The SVR rate in genotypes 2 and 3 are $73.3 \%-100 \%$ if treated for 24 weeks while genotypes 1 and 4 show overall SVR rate $22 \%-54.5 \%$ with 48 weeks of therapy as shown in table-I and II. 


\begin{tabular}{|c|c|c|c|c|c|c|}
\hline $\begin{array}{l}\text { Name of } \\
\text { the study }\end{array}$ & $\begin{array}{l}\text { Kowala-Piaskowska et al } \\
2007 \text { (10) } \\
\text { Total cases studied=30 } \\
\text { Age of studied group 8-19 } \\
\text { years }\end{array}$ & $\begin{array}{l}\text { Baker et al } 2007 \text { (11) } \\
\text { Total cases studied =10 } \\
\text { Age of studied group 11-18 } \\
\text { years }\end{array}$ & $\begin{array}{l}\text { Jara et al } 2008(12) \\
\text { Total cases studied=30 } \\
\text { Age of studied group 3-16 } \\
\text { years }\end{array}$ & $\begin{array}{l}\text { Tajiri at al } 2009(13) \\
\text { Total cases studied }=37 \\
\text { Age of studied group 7-30 } \\
\text { years }\end{array}$ & $\begin{array}{l}\text { Wirth at al } 2010(14) \\
\text { Total cases studied = } 107 \\
\text { Age of studied group 3-17 } \\
\text { years }\end{array}$ & $\begin{array}{l}\text { Al Ali at al } 2010(15) \\
\text { Total cases studied = } 12 \\
\text { Age of studied group 14-17 } \\
\text { years }\end{array}$ \\
\hline $\begin{array}{l}\text { Early viral response (EVR) } \\
\text { both complete and } \\
\text { incomplete }\end{array}$ & $*_{-}$ & $*_{-}$ & $\begin{array}{l}70 \% \text { cases (out of which } \\
71.43 \% \text { was complete EVR } \\
\text { while } 28.57 \% \text { partial EVR) }\end{array}$ & $\begin{array}{l}\text { *- } \\
\text { Complete EVR in } 86 \% \\
\text { cases }\end{array}$ & 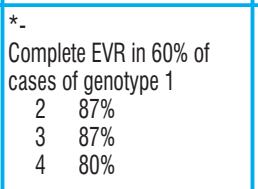 & $\begin{array}{l}\text { *- } \\
\text { Complete EVR in 83\% } \\
\text { cases }\end{array}$ \\
\hline $\begin{array}{l}\text { End treatment response } \\
\text { (ETR) }\end{array}$ & $70 \%$ cases & $70 \%$ cases & $\begin{array}{l}60 \% \text { cases (ETR in case } \\
\text { with genotype } 3 \text { was } \\
100 \% \text {, with genotype } 1 \text { was } \\
58 \% \text { and with genotype } \\
4 \text { was } 00 \% \text { ) }\end{array}$ & $*_{-}$ & \begin{tabular}{|l|} 
ETR in cases with genotype \\
1 was $60 \%$, with genotype \\
2 was $93 \%$, with genotype \\
3 was $93 \%$ and with \\
genotype 4 was $80 \%$
\end{tabular} & $\begin{array}{l}10(83 \%) \text { cases at } 48 \\
\text { weeks of treatment }\end{array}$ \\
\hline $\begin{array}{l}\text { Sustained viral response } \\
\text { (SVR) }\end{array}$ & $70 \%$ cases & $\begin{array}{l}30 \% \text { cases (SVR in cases } \\
\text { with genotype } 1 \text { was } 22 \% \\
\text { while with genotype } 2 \text { was } \\
100 \% \text { ) }\end{array}$ & $\begin{array}{l}50 \% \text { cases (SVR in cases } \\
\text { with genotype } 3 \text { was } 100 \% \text {, } \\
\text { with genotype } 1 \text { was } 44 \% \\
\text { and with genotype } 4 \text { was } \\
00 \% \text { ) }\end{array}$ & $\begin{array}{l}73 \% \text { cases (SVR in cases } \\
\text { with genotype } 2 \text { was } 54.5 \% \\
\text { and with genotype } 2 \text { was } \\
73.3 \% \text { ) }\end{array}$ & \begin{tabular}{|l|}
$65 \%$ cases (SVR in cases \\
with genotype 1 was $53 \%$, \\
with genotype 2 was $93 \%$, \\
with genotype 3 was $93 \%$ \\
and with genotype 4 was $80 \%$
\end{tabular} & $9(75 \%)$ \\
\hline Breakthrough & $*_{-}$ & $10 \%$ & $6.6 \%$ & - & $*_{-}$ & - \\
\hline Relapse & $13 \%$ & $40 \%$ & $3.3 \%$ & $15 \%$ & $1 \%$ & $8 \%$ \\
\hline Nonresponder & $30 \%$ & $10 \%$ & $40 \%$ & $3.3 \%$ & *- & $17 \%$ \\
\hline $\begin{array}{l}\text { The lowest limit of HCV } \\
\text { RNA detected by the test } \\
\text { used }\end{array}$ & $50 \mathrm{IU} / \mathrm{ml}$ & $10 \mathrm{IU} / \mathrm{ml}$ & $50 \mathrm{IU} / \mathrm{ml}$ & $50 \mathrm{IU} / \mathrm{ml}$ & $125 \mathrm{lU} / \mathrm{ml}$ & $50 \mathrm{IU} / \mathrm{ml}$ \\
\hline Genotype causing infection & $\begin{array}{l}\text { Genotype } 1 \text { responsible in } \\
97 \% \text { while genotype } 4 \text { in } \\
3 \% \text { cases }\end{array}$ & $\begin{array}{l}\text { Genotype } 1 \text { responsible in } \\
90 \% \text { while }\end{array}$ & $\begin{array}{l}\text { Genotype } 1 \text { responsible in } \\
87 \% \text {, genotype } 3 \text { in 10\% } \\
\text { while genotype } 4 \text { in 3\% } \\
\text { cases }\end{array}$ & $\begin{array}{l}\text { Genotype } 1 \text { responsible in } \\
59 \% \text { while genotype } 2 \text { in } \\
41 \% \text { cases }\end{array}$ & $\begin{array}{l}\text { Genotype } 1 \text { responsible in } \\
67 \% \text {, genotype }\end{array}$ & $\begin{array}{l}\text { Genotype } 4 \text { responsible for } \\
100 \%\end{array}$ \\
\hline $\begin{array}{l}\text { Mode of acquiring infection } \\
\text { Vertical Parenteral } \\
\text { Unknown }\end{array}$ & - & $\begin{array}{l}30 \% \\
60 \% \\
10 \%\end{array}$ & $\begin{array}{l}70 \% \\
30 \% \\
0 \%\end{array}$ & $\begin{array}{l}38 \% \\
59 \% \\
3 \%\end{array}$ & $\begin{array}{l}70 \% \\
11 \% \\
19 \%\end{array}$ & $\begin{array}{l}18 \% \\
42 \% \\
42 \%\end{array}$ \\
\hline $\begin{array}{l}\text { Liver histopathology of } \\
\text { studied children }\end{array}$ & $\begin{array}{l}\text { Mild severity of disease and } \\
\text { staging not exceeding } 2 \\
\text { points }\end{array}$ & $\begin{array}{l}\text { Grade I was in } 70 \% \text { cases } \\
\text { while grade } 2 \text { in 30\% cases }\end{array}$ & $\begin{array}{l}\text { Knodell index of } 1-8<4 \\
\text { was } 58 \%, 4-7 \text { in } 31 \% \text { while } \\
\geq 8 \text { in } 10 \% \text { while there was } \\
\text { no case of cirrhosis }\end{array}$ & - & $\begin{array}{l}\text { Metavir score showed F0 in } \\
12.5 \%, \text { F1 in } 84.6 \% \text {, F2 in } \\
1.9 \% \text {, F3 in } 1 \% \text { while none } \\
\text { had cirrhosis. Steatosis was } \\
\text { absent in } 71 \% \text { while } \leq 5 \% \\
\text { in } 22 \% \text { cases }\end{array}$ & $\begin{array}{l}\text { Histologic grade was } 1.67 \\
\text { (mean) while fibrosis score } \\
\text { was } 0.67 \text { (mean) according } \\
\text { to Metavir score. }\end{array}$ \\
\hline Case with normal ALT level & - & $40 \%$ cases & $6.66 \%$ cases & $27 \%$ cases & $59 \%$ cases & $17 \%$ cases \\
\hline $\begin{array}{l}\text { Children with history of use } \\
\text { of interferon or ribavirin } \\
\text { therapy in the past }\end{array}$ & 6 children & 3 children & $\begin{array}{l}6 \text { children. Only } 1 \text { of these } \\
\text { children achieved SVR in } \\
\text { this study }\end{array}$ & $\begin{array}{l}18 \text { cases. SVR achieved, } \\
\text { during this study, in these } \\
\text { cases was } 67 \%\end{array}$ & Excluded & - \\
\hline $\begin{array}{l}\text { Any special comments on } \\
\text { cases recruited }\end{array}$ & $\begin{array}{l}20 \text { cases of pediatric } \\
\text { malignancy were included } \\
\text { Autoantibodies were tested } \\
\text { at the start of study. }\end{array}$ & $\begin{array}{l}3 \text { cases of hemophilia } 3 \\
\text { and on case of IV drug user } \\
\text { were included. }\end{array}$ & $\begin{array}{l}\text { One case of clotting factor } \\
\text { X deficiency, on case of } \\
\text { agammaglobulinemia, one } \\
\text { case of acute lymphocytic } \\
\text { leukemia and three cases of } \\
\text { cardiomyopathies were } \\
\text { included. Autoantibodies } \\
\text { were tested at the start of } \\
\text { study. }\end{array}$ & $\begin{array}{l}7 \text { cases of malignancy in, } \\
5 \text { cases of trisomy } 21 \text { were } \\
\text { included, in } 5 \text { cases } \\
\text { Autoantibodies were tested } \\
\text { at the start of study. }\end{array}$ & - & None \\
\hline $\begin{array}{l}\text { Ribavirin dosage in per } \\
\text { kilogram per day }\end{array}$ & $15 / \mathrm{mg} / \mathrm{kg}$ & $\begin{array}{l}\text { Ribavirin } 800 \mathrm{mg} / \mathrm{day} \text { as } \\
\text { the age of patients are } \\
14-17 \text { years }\end{array}$ & $15 / \mathrm{mg} / \mathrm{kg}$ & $15 / \mathrm{mg} / \mathrm{kg}$ & $15 / \mathrm{mg} / \mathrm{kg}$ & $15 / \mathrm{mg} / \mathrm{kg}$ \\
\hline
\end{tabular}




\begin{tabular}{|c|c|c|c|c|}
\hline \multirow[t]{2}{*}{ Name of the study } & \multirow{2}{*}{$\begin{array}{l}\text { Schwarz et al } 2006(16) \\
\text { Total cases studied } 14 \\
\text { Age of studied group 2-8 } \\
\text { years }\end{array}$} & \multirow{2}{*}{$\begin{array}{l}\text { Sokal et al } 2010 \text { (18) } \\
\text { Total cases studied } 65 \\
\text { (group A } 18 \text { while group B }_{47 \text { cases) }}{ }^{\star *} \\
\text { Age of studied group 6-17 } \\
\text { years }\end{array}$} & \multicolumn{2}{|c|}{$\begin{array}{l}\text { Schwarz et al } 201108 \text { (17) } \\
\text { Total cases studied } 114 \\
\text { Age of studied group 5-18 years }\end{array}$} \\
\hline & & & $\begin{array}{l}\text { Combined therapy (peginterferon plus } \\
\text { rebavirin) } \\
\text { Total cases studied } 55\end{array}$ & $\begin{array}{l}\text { Mono therapy (peginterferon only) } \\
\text { Total cases studied } 59\end{array}$ \\
\hline $\begin{array}{l}\text { Early viral response (EVR) both } \\
\text { complete and incomplete }\end{array}$ & $\begin{array}{l}50 \% \text { cases (complete EVR in } 86 \% \\
\text { while partial EVR in } 14 \% \text { cases) }\end{array}$ & $\begin{array}{l}83 \% \text { cases in group A while } 57 \% \\
\text { cases in group B }\end{array}$ & $*_{-}$ & $*_{-}$ \\
\hline End treatment response (ETR) & $50 \%$ cases & $\begin{array}{l}94 \% \text { cases in group A while } 57 \% \\
\text { cases in group B }\end{array}$ & $65 \%$ cases & $37 \%$ cases \\
\hline Sustained viral response (SVR) & $43 \%$ cases (all were from genotype 1 ) & $\begin{array}{l}89 \% \text { cases in group A while } 57 \% \\
\text { cases in group B }\end{array}$ & $\begin{array}{l}53 \% \text { cases ( } 47 \% \text { in cases with } \\
\text { genotype } 1 \text { while } 80 \% \text { in case } \\
\text { genotypes } 2-3 \text { ) }\end{array}$ & $\begin{array}{l}201 \% \text { cases (17\% in case with } \\
\text { genotype } 1 \text { while } 36 \% \text { in genotype 2-3) }\end{array}$ \\
\hline Breakthrough & $7 \%$ & $*_{-}$ & $15 \%$ & $8 \%$ \\
\hline Relapse & $7 \%$ & $*_{-}$ & $17 \%$ & $45 \%$ \\
\hline Nonresponder & $43 \%$ & $*_{-}$ & $*_{-}$ & $*_{-}$ \\
\hline $\begin{array}{l}\text { The lowest limit of HCV RNA detected } \\
\text { by the test used }\end{array}$ & $50 \mathrm{IU} / \mathrm{ml}$ & $50 \mathrm{IU} / \mathrm{ml}$ & $50 \mathrm{IU} / \mathrm{ml}$ & $50 \mathrm{IU} / \mathrm{ml}$ \\
\hline Genotype causing infection & $\begin{array}{l}\text { Genotype } 1 \text { responsible in } 93 \% \text { while } \\
\text { non-genotype } 1 \text { in } 7 \% \text { cases }\end{array}$ & $\begin{array}{l}\text { Group A (genotype } 3 \text { responsible in } \\
11 \% \text { cases) } \\
\text { Group B (genotype } 1 \text { responsible in } \\
96 \% \text { while genotype } 4 \text { in } 2 \% \text { cases) } \\
\text { Type } 5 \quad 2 \%\end{array}$ & $\begin{array}{l}\text { Genotype } 1 \text { responsible in } 82 \% \text { while } \\
\text { genotype 2-3 in } 18 \% \text { cases }\end{array}$ & $\begin{array}{l}\text { Genotype } 1 \text { responsible in } 80 \% \text { while } \\
\text { genotype 2-3 in 20\% cases }\end{array}$ \\
\hline $\begin{array}{l}\text { Mode of acquiring infection } \\
\text { Vertical } \\
\text { Parenteral } \\
\text { Unknown }\end{array}$ & $\begin{array}{l}79 \% \text { cases } \\
7 \% \text { cases } \\
14 \% \text { cases }\end{array}$ & $\begin{array}{l}\text { Group A (vertical in } 55.5 \% \text {, parenteral } \\
\text { in } 38.9 \% \text { and unknown in } 5.5 \% \text { cases) } \\
\text { Group B (vertical in } 42.5 \% \text {, parenteral } \\
\text { in } 29.8 \% \text { while unknown in } 27.7 \% \\
\text { cases) }\end{array}$ & $\begin{array}{l}71 \% \\
*_{-} \\
*_{-}\end{array}$ & $\begin{array}{l}80 \% \\
*_{-} \\
*_{-}\end{array}$ \\
\hline Liver histopathology of studied children & $\begin{array}{l}\text { None of the child had fibrosis } \\
\text { according to Ishak's modified } \\
\text { histological activity index used. }\end{array}$ & $\begin{array}{l}\text { No fibrosis in } 44.4 \% \text { cases of group } \\
\text { A while no fibrosis in } 55.3 \% \text { cases of } \\
\text { group B according to Metavir score } \\
\text { used. }\end{array}$ & - & - \\
\hline Cases with normal ALT level & None & $\begin{array}{l}\text { Normal ALT level in } 55 \% \text { cases of } \\
\text { group A and in } 43 \% \text { cases of group B. }\end{array}$ & $*_{-}$ & *- \\
\hline $\begin{array}{l}\text { Children with history of use of } \\
\text { interferon or ribavirin therapy in the past }\end{array}$ & Excluded & Not mentioned & Excluded & Excluded \\
\hline $\begin{array}{l}\text { Any special comments on case } \\
\text { recruited }\end{array}$ & - & - & - & - \\
\hline $\begin{array}{l}\text { Riavirin dosage in per kilogram per } \\
\text { day }\end{array}$ & Not used & $15 \mathrm{mg} / \mathrm{kg}$ & $15 \mathrm{mg} / \mathrm{kg}$ & Not used \\
\hline **Group & $\begin{array}{l}{ }^{*} \text {-exact valu } \\
\text { having infection with ge } \\
\text { Drug dose moa }\end{array}$ & $\begin{array}{l}\text { in unknown -no de } \\
\text { type } 2,3 \text { while group } B h \\
\text { cation* }\end{array}$ & $\begin{array}{l}\text { ta is available } \\
\text { ving infection with geno } \\
\text { Drug stopped** }\end{array}$ & $1,4,5,6$ \\
\hline
\end{tabular}

Baker et al $2007^{11}$ and Jara et al $2008^{12}$ treated genotype 2 and 3 for 24 weeks, Wirth et al $2010^{14}$ treated genotype 2 and the genotype 3 having viral load $<600,000 \mathrm{iu} / \mathrm{ml}$ for 24 week while for 48 weeks if viral load $\geqslant 600,000 \mathrm{iu} / \mathrm{l}$ but treatment was stopped at 24 weeks if HCV RNA was positive at 24 weeks or $<2$ log reduction in HCV RNA at 12 weeks of treat and Tajiri et al $2009^{13}$ treated genotype 2 with 24 or 48 weeks with peginterferon $a-2 b$. Baker et al $2007^{11}$, Jara et al $2008^{12}$ and Al Ali et al $2010^{15}$ treated genotype 1 and 4 for 48 weeks, Tajiri et al $2009^{13}$ treated genotype 1 for 48 weeks. Kowala-Piaskowska et al 2007 treated 
genotype 1 and 4 for 48 weeks but treatment was stopped at 24 weeks if no virological response (except in 4 cases where 48 weeks treatment was given $)^{10}$. Wirth et al $2010^{14}$ treated the genotype 1 and 4 for 48 weeks but the treatment was stopped at 24 weeks if HCV RNA was positive at 24 weeks or $<2$ log reduction in HCV RNA at 12 weeks of treatment with peginterferon $\alpha-2 b$.

Schwarz et al $2006^{16}$ treated genotype1 for 48 weeks. Sokal et al $2010^{18}$ treated genotype 2 and 3 for 24 week while genotype 1,4,5 and 6 for 48 weeks if HCV RNA became negative at 24 weeks $^{18}$. Schwarz et al $2011^{17}$ treated genotype 1, 2 and 3 for 48 weeks but treatment was stopped at 24 weeks if HCV RNA positive ${ }^{17}$ with peginterferon $a-2 b$

Jara et al $2008^{12}$ showed that the proportion of patients who attained HCV RNA negativity increased with time during the first 24 weeks of therapy of all genotypes but prolongation of treatment beyond 24 weeks (i.e. 48 weeks) in cases of Genotype 1 and 4 did not improve viral clearance or SVR ${ }^{12}$. Tajiri et al $2009^{13}$ showed that 16 out of 22 patients with genotype 1 received 48week therapy and 12 of the 16 achieved a SVR. The other four had 72-week therapy and all of them achieved a SVR. The Infectious Diseases Society of America and the American College of Gastroenterology 2009 recommended duration of treatment in children for 48 weeks irrespective of genotype ${ }^{9}$. Hu et al $2010^{22}$ in a systematic review showed that there was insufficient data to assess the applicability of the week 12 stop rule (stopping therapy at week 12 if there is less than a 2 log drop in HCV RNA) or the efficacy of shortening therapy to 24 weeks in children with genotype 2 and 3 . If HCV RNA remains detectable between 12 to 24 weeks of therapy, therapy may be extended to 72 weeks ${ }^{13}$.

Although there is insufficient data but it may be may be proposed that, due to the high probability of a favorable response in the case of a sensitive genotype $(2,3$ genotypes), all patients with genotype 2 and 3 be treated for 24 weeks while in the case of less-sensitive genotypes (1,4 genotypes), re-evaluation be carried out after 24 weeks. If at this point the viral load is negative, treatment is continued up to 48 weeks, otherwise the treatment may be withdrawn, since healing is unlikely to occur even if the full treatment course is administered ${ }^{12,18}$.

The minimum age at which peginterferon $\alpha-2 a$ used was 2 years ${ }^{16}$ while for peginterferon $\alpha-2 b$ it was 3 years $^{12}$. The Infectious Diseases Society of America and the American College of Gastroenterology 2009 also recommended that all children with chronic hepatitis $\mathrm{C}$ with a minimum age of two years should be considered appropriate candidates for treatment ${ }^{9}$.

\section{ADVERSE EFFECTS OF PEGINTERFERON \pm RIBAVIRIN}

The adverse effects of peginterferon plus ribavirin are similar to those associated with conventional interferon plus ribavirin but involve fewer injections and immediate injection reactions. The adverse effects noted in different studies done in children on peginterferon \pm ribavirin are shown in table-III. Febrile convulsions are a hazard in younger children but the problem did not occur. Reduction or discontinuation (temporary or permanent) of interferon and/or ribavirin may ameliorate adverse effects. However, this may also jeopardize the success of treatment ${ }^{9,23}$.

Leucocyte, neutrophil and platelet counts tend to decrease during the initial period of treatment and, subsequently, these counts stabilize but may stay below the normal range for the remainder of the treatment period increasing rapidly to baseline values after the completion of treatment ${ }^{18}$.

Weight loss/height inhibition may occur during the treatment phase but most patients experience compensatory weight gain after the stoppage of treatment ${ }^{12,14,10}$. Endocrine abnormalities may occur 
during treatment. Detectable antithyroid antibodies are particularly common and clinical hypothyroidism may occur, which rarely become permanent ${ }^{10,12,13,14,15}$. In other instances abnormally high levels of thyroidstimulating hormone may occur ${ }^{14,18}$. Rarely thyrotoxicosis may develop ${ }^{12,18}$. Insulin dependant diabetes mellitus may develop very rarely ${ }^{15,17}$. Very limited data shows that in those children who have not received interferon HCV infection associated ophthalmologic changes do not occur ${ }^{24}$. The ophthalmologic complications are infrequent (2-3\%) in children who are treated with peginterferon $a-2 b$ for HCV but these complications may be serious e.g. ischemic retinopathy and uveitis necessitating, prospective ocular assessment ${ }^{17,24}$. The effects on eye may be irreversible in adults ${ }^{25}$ but because of limited data in children no inference can be drawn.

The most common adverse effect of ribavirin is a reversible hemolytic anemia, which occurs due to accumulation of phosphorylated ribavirin in erythrocytes which shortens the life span of erythrocytes. A fall in hemoglobin level between 2 and $3 \mathrm{~g} / \mathrm{dL}$ within 4 weeks of starting combination therapy is common ${ }^{23}$. Reticulocyte count increases during therapy but returns to normal thereafter ${ }^{12}$. Anemia is the most common reason for ribavirin dose reduction or treatment discontinuation. Ribavirin may also cause

\begin{tabular}{|c|c|c|c|}
\hline Adverse Effect & Range (\%) & $\begin{array}{c}\text { Drug does } \\
\text { modification* }\end{array}$ & $\begin{array}{c}\text { Drug } \\
\text { stopped }^{* *}\end{array}$ \\
\hline $\begin{array}{l}\text { Blood } \\
\text { Leucopenia }(10,11,12,13,14,15) \\
\text { Hemoglobin }<10 \text { gm\% }(10,11,13,14,15,18) \\
\text { Neutropenia }(11,12,14,15,18) \\
\text { Thrombocytepenia }(13,14,18)\end{array}$ & $\begin{array}{c}0-67 \% \\
5-33 \% \\
0-33 \% \\
1.5-11 \%\end{array}$ & $\begin{array}{l}\text { Yes } \\
\text { Yes } \\
\text { Yes } \\
\text { No }\end{array}$ & $\begin{array}{l}\text { No } \\
\text { No } \\
\text { No } \\
\text { Yes }\end{array}$ \\
\hline $\begin{array}{l}\text { General } \\
\text { Fever }(10,11,12,13,14,15,16,17,18) \\
\text { Headache }(10,12,13,14,16,17,18) \\
\text { Lethargy }(10,13,14,18) \\
\text { Weakness }(10,12,14) \\
\text { Weight loss }(11,12,14) \\
\text { Effect on height }(12,14) \\
\text { Chills }(10,14) \\
\text { Lymphadenopathy (10) } \\
\text { Bleeding (11) }\end{array}$ & $\begin{array}{c}54-100 \% \\
27-67 \% \\
7-54 \% \\
15-73 \% \\
19-100 \% \\
70-73 \% \\
16-21 \% \\
6 \% \\
9 \%\end{array}$ & $\begin{array}{l}\text { No } \\
\text { No } \\
\text { Yes } \\
\text { No } \\
\text { Yes } \\
\text { No } \\
\text { No } \\
\text { No } \\
\text { No }\end{array}$ & $\begin{array}{l}\text { Yes } \\
\text { No } \\
\text { Yes } \\
\text { No } \\
\text { No } \\
\text { No } \\
\text { No } \\
\text { No } \\
\text { No }\end{array}$ \\
\hline $\begin{array}{l}\text { Gastrointestinal } \\
\text { Anorexia }(10,12,13,14,17,18) \\
\text { Vomiting/nausea }(10,12,13,14,16,18) \\
\text { Abdominal pain }(10,12,13,14,18) \\
\text { Diarrhoea }(10,18) \\
\text { Hepatitis }(16,18) \\
\text { Feeling of dry mouth }(10) \\
\text { Pain in gingiva (10) } \\
\text { Stomatitis (13) } \\
\text { Constipation (12) }\end{array}$ & $\begin{array}{c}8-76 \% \\
13-45 \% \\
5-43 \% \\
3-14 \% \\
1.5-14 \% \\
13 \% \\
6 \% \\
8 \% \\
10 \%\end{array}$ & $\begin{array}{l}\text { No } \\
\text { Yes } \\
\text { No } \\
\text { Yes } \\
\text { No } \\
\text { No } \\
\text { No } \\
\text { No } \\
\text { No }\end{array}$ & $\begin{array}{l}\text { No } \\
\text { No } \\
\text { No } \\
\text { No } \\
\text { Yes } \\
\text { No } \\
\text { No } \\
\text { No } \\
\text { No }\end{array}$ \\
\hline $\begin{array}{l}\text { Nervous System } \\
\text { Irritability }(10,12,13,14,16,17,18) \\
\text { Sleep disturbance }(13,14,15,17,18) \\
\text { Apathy }(10,12,13) \\
\text { Drowsiness }(10,15)\end{array}$ & $\begin{array}{c}8-34 \% \\
3-27 \% \\
5-23 \% \\
15-58 \%\end{array}$ & $\begin{array}{l}\text { No } \\
\text { No } \\
\text { No } \\
\text { No }\end{array}$ & $\begin{array}{l}\text { No } \\
\text { No } \\
\text { No } \\
\text { No }\end{array}$ \\
\hline
\end{tabular}




\begin{tabular}{|c|c|c|c|}
\hline $\begin{array}{l}\text { Depression }(11,14) \\
\text { Dizziness }(10,14) \\
\text { Psychiatric adverse effects (14) } \\
\text { Suicidal attempt (17) }\end{array}$ & $\begin{array}{c}2-20 \% \\
9-14 \% \\
28 \% \\
1 \%\end{array}$ & $\begin{array}{l}\text { Yes } \\
\text { No } \\
\text { No } \\
\text { No }\end{array}$ & $\begin{array}{l}\text { No } \\
\text { No } \\
\text { No } \\
\text { Yes }\end{array}$ \\
\hline $\begin{array}{l}\text { Skin } \\
\text { Redness at the injection site }(10,12,13,14,16,17,18) \\
\text { Hair loss }(10,12,13,14,18) \\
\text { Rash }(10,17) \\
\text { Dry skin/dermatitis }(12,18) \\
\text { Pruritus }(12,18)\end{array}$ & $\begin{array}{c}8-46 \% \\
9-24 \% \\
3-24 \% \\
10-29 \% \\
6-7 \%\end{array}$ & $\begin{array}{l}\text { No } \\
\text { No } \\
\text { No } \\
\text { No } \\
\text { Yes }\end{array}$ & $\begin{array}{l}\text { No } \\
\text { No } \\
\text { No } \\
\text { No } \\
\text { No }\end{array}$ \\
\hline $\begin{array}{l}\text { Endocrine } \\
\text { Transient high TSH or T4 }(12,14,18) \\
\text { Hypothyroidism }(10,13,14,15,18) \\
\text { Thyrotoxicosis }(12,18) \\
\text { Antithyroid antibodies }(12,13) \\
\text { Diabetes mellitus }(15,17)\end{array}$ & $\begin{array}{c}11-25 \% \\
1.5-8 \% \\
1.5-7 \% \\
14.16 \% \\
2-8 \%\end{array}$ & $\begin{array}{l}\text { No } \\
\text { No } \\
\text { No } \\
\text { No } \\
\text { No }\end{array}$ & $\begin{array}{l}\text { No } \\
\text { No } \\
\text { Yes } \\
\text { No } \\
\text { Yes }\end{array}$ \\
\hline $\begin{array}{l}\text { Other } \\
\text { Pain in joints }(10,12,14,17,18) \\
\text { Muscle pain }(10,14,18) \\
\text { Lumbar pain }(10) \\
\text { Bacterial infections }(18) \\
\text { Viral infections }(18) \\
\text { Upper respiratory infections (12) } \\
\text { Gastrointestinal infections (12) } \\
\text { Skin infections }(12) \\
\text { Cough }(10) \\
\text { Sore throat }(10,12,18) \\
\text { Chest pain }(10) \\
\text { Cough (10) } \\
\text { Breathlessness }(18) \\
\text { Pulmonary hypertension in (18) } \\
\text { Nose bleed (12) } \\
\text { Enuresis-dysuria (18) } \\
\text { Palpitations (18) } \\
\text { Reversible eye problems (17) } \\
\text { Pain in the eye bulbs }(10) \\
\text { Autoantobodies ANA (12) } \\
\text { Increased Triglycerides (16) }\end{array}$ & $\begin{array}{c}3-45 \% \\
9-35 \% \\
26 \% \\
9 \% \\
14 \% \\
53 \% \\
30 \% \\
13 \% \\
7 \% \\
3-40 \% \\
3 \% \\
7 \% \\
11 \% \\
1.5 \% \\
10 \% \\
3 \% \\
3 \% \\
4 \% \\
3 \% \\
23 \% \\
1 \%\end{array}$ & $\begin{array}{l}\text { No } \\
\text { No } \\
\text { No } \\
\text { No } \\
\text { No } \\
\text { No } \\
\text { No } \\
\text { No } \\
\text { No } \\
\text { No } \\
\text { No } \\
\text { No } \\
\text { No } \\
\text { No } \\
\text { No } \\
\text { No } \\
\text { No } \\
\text { No } \\
\text { No } \\
\text { No } \\
\text { No }\end{array}$ & $\begin{array}{l}\text { No } \\
\text { No } \\
\text { No } \\
\text { No } \\
\text { No } \\
\text { No } \\
\text { No } \\
\text { No } \\
\text { No } \\
\text { No } \\
\text { No } \\
\text { No } \\
\text { No } \\
\text { No } \\
\text { No } \\
\text { No } \\
\text { No } \\
\text { No } \\
\text { No } \\
\text { No } \\
\text { Yes }\end{array}$ \\
\hline
\end{tabular}

mild lymphopenia, hyperuricemia, itching, rash, cough and nasal stuffiness ${ }^{9}$. Since in most of the studies (except in some cases in the study by Schwarz et al 2008) used both peginterferon and ribavirin it iis difficult to differentiate the contribution of each drugs for the side effects mentioned in table-III. It is known to be teratogenic ${ }^{23}$ and thus it is imperative for persons who receive the drug to use strict contraceptive methods both during treatment and for a period of 6 months thereafter.

THE ROLE OF LIVER BIOPSY IN THE INITIATION OF TREATMENT

The role and utility of liver biopsy in the initiation of 
treatment of hepatitis $\mathrm{C}$ cases is still debatable, and no definite consensus exists in any guideline. The treatment may be started without liver biopsy ${ }^{13,17}$.

\section{CONCLUSIONS}

Peginterferon $\alpha-2 b$ and peginterferon $\alpha-2 a$ in combination with ribavirin may be used in children above two years of age having chronic hepatitis $\mathrm{C}$ but is not indicated in every case. The therapy is not free from side effects as in adults.

\section{Copyright@ 16 Feb, 2013.}

\section{REFERRENCES}

1. Robinson JL, Doucette K. The natural history of hepatitis $\mathrm{C}$ virus infection acquired during childhood. Liver Int. 2012; 32(2):258-70.

2. Porto AF, Tormey L, Lim JK. Management of chronic hepatitis C infection in children. Curr Opin Pediatr. $2012 ; 24(1): 113-20$.

3. Mohan N, Gonza 'lez-Peralta RP, Fujisawa T, Chang MH, Heller S, Jara P, et al. Chronic Hepatitis C Virus Infection in Children. J Pediatr Gastroenterol Nutr 2010; 50 (2): 123- 131.

4. Serranti D, Buonsenso D, Ceccarelli M, Gargiullo L, Ranno 0, Valentini P. Pediatric hepatitis C infection: to treat or not to treat.... what's the best for the child? Eur Rev Med Pharmacol Sci. 2011;15(9):1057-67.

5. Jhaveri R. Diagnosis and management of hepatitis C virus-infected children. Pediatr Infect Dis J. 2011;30 (11):983-5.

6. Rodrigue JR, Balistreri W, Haber B, Jonas MM, Mohan P, Molleston JP, et al. Peginterferon with or without ribavirin has minimal effect on quality of life, behavioral/emotional, and cognitive outcomes in children. Hepatology. 2011;53(5):1468-75.

7. Mack CL, Gonzalez-Peralta RP, Gupta N, Leung D, Narkewicz MR, Roberts EA, Rosenthal P, Schwarz KB NASPGHAN practice guidelines: Diagnosis and management of hepatitis C infection in infants, children, and adolescents. J Pediatr Gastroenterol Nutr. 2012 Jun;54(6):838-55.
8. Jara P, Hierro L. Treatment of hepatitis C in children. ExpertRev Gastroenterol Hepatol 2010; 4: 51-61.

9. Ghany MG, Strader DB, Thomas DL, Seeff LB. Diagnosis, Management, and Treatment of Hepatitis C: An Update. Hepatology 2009; 49(4): 1335-74.

10. Kowala-Piaskowska A, Mozer-Lisewska I, Figlerowicz $M$, Słuzewski W. Adverse effects during the treatment with pegylated interferon and ribavirin in children with chronic hepatitis C. Pharmacoepidemiol Drug Saf 2007; 16(10): 1095-103

11. Baker RD, Dee D, Baker SS. Response to pegylated interferon alpha-2b and ribavirin in children with chronic hepatitis C. J Clin Gastroenterol 2007; 41(1): 111-4.

12. Jara P, Hierro L, de la Vega A, Díaz C, Camarena C, Frauca $E$, et al. Efficacy and safety of peginterferonalpha2b and ribavirin combination therapy in children with chronic hepatitis C infection. Pediatr Infect Dis J 2008; 27(2): 142-8.

13. Tajiri H, Inui A, Kiyohara Y, Suzuki M, Kagimoto S, Etani $\mathrm{Y}$, et al. Peginterferon alpha-2b and ribavirin for the treatment of chronic hepatitis $C$ in Japanese pediatric and young adult patients: a survey of the Japan Society of Pediatric Hepatology. Eur J Gastroenterol Hepatol 2009; 21(11): 1256-60.

14. Wirth S, Ribes-Koninckx C, Calzado MA, Bortolotti F, Zancan $L$, Jara $P$, et al. High sustained virologic response rates in children with chronic hepatitis $\mathrm{C}$ receiving peginterferon alfa-2b plus ribavirin. $J$ Hepatol 2010; 52(4): 501-7.

15. Al Ali J, Owayed S, Al-Qabandi W, Husain K, Hasan F. Pegylated interferon alfa-2b plus ribavirin for the treatment of chronic hepatitis C genotype 4 in adolescents. Ann Hepatol 2010; 9(2): 156-60.

16. Schwarz KB, Mohan P, Narkewicz MR, Molleston JP, Nash SR, Hu S, et al. Safety, efficacy and pharmacokinetics of peginterferon alpha2a $(40 \mathrm{kd})$ in children with chronic hepatitis C. J Pediatr Gastroenterol Nutr 2006; 43(4): 499-505.

17. Schwarz KB, González-Peralta RP, Murray K, Malleston J, Haber B, Jones M, et al. The combination of ribavirin 
and peginterferon is superior to peginterferon and placebo for children and adolescents with chronic hepatitis C. Gastroenterology. 2011;140(2):450-458.

18. Sokal EM, Bourgois A, Stéphenne X, Silveira T, Porta G, Gardovska D, et al. Peginterferon alfa-2a plus ribavirin for chronic hepatitis $\mathrm{C}$ virus infection in children and adolescents. J Hepatol 2010; 52(6): 82731.

19. Ascione A, De Luca M, Tartaglione MT, Lampasi F, Di Costanzo GG, Lanza AG, et al. Peginterferon alfa-2a plus ribavirin is more effective than peginterferon alfa-2b plus ribavirin for treating chronic hepatitis C virus infection. Gastroenterology 2010; 138(1): 11622.

20. Rustgi VK, Esposito S, Hamzeh FM, Shiffman ML. Peginterferon alfa-2a/ribavirin in hepatitis $C$ virus patients nontolerant or nonresponsive to peginterferon alfa-2b/ribavirin. Aliment Pharmacol Ther 2008; $27(5):$ 433-40.

21. Rumi MG, Aghemo A, Prati GM, D'Ambrosio R, Donato MF, Soffredini R, et al. Randomized study of peginterferon-alpha2a plus ribavirin vs peginterferon-alpha2b plus ribavirin in chronic hepatitis $\mathrm{C}$.

\section{AUTHOR(S):}

1. DR. ABDUL REHMAN

MBBS, DCH, FCPS

Assistant Professor of Paediatrics,

Quaid-e-Azam Medical College, Bahawalpur.
Gastroenterology 2010; 138(1): 108-15.

22. Hu J, Doucette K, Hartling L, Tjosvold L, Robinson J. Treatment of Hepatitis C in Children: A Systematic Review. PLoS ONE 2010; 5(7): e11542 Available at: Http://www.plosone.org/article/info\%3Adoi\%2F10.13 71\%2Fjournal.pone.0011542. Downloaded on 25-082010

23. Davison SM, Kelly DA. Management strategies for hepatitis C virus infection in children. Paediatr Drugs 2008; 10 (6): 57-65.

24. Narkewicz MR, Rosenthal P, Schwarz KB, Drack A, Margolis T, Repka MX; PEDS-C Study Group. Ophthalmologic complications in children with chronic hepatitis $\mathbf{C}$ treated with pegylated interferon. J Pediatr Gastroenterol Nutr 2010; 51(2):183-6.

25. Seddik H, Tamzaourte M, Rouibaa F, Fadlouallah M, Benkirane A. Irreversible Anterior Ischemic Optic Neuropathy Complicating Interferon Alpha and Ribaverin Therapy. International Journal of Hepatology 2011; volume2011: Article ID 814242. Available at: http://www.sage-hindawi.com/journals/ ijhep/2011/814242/ (accessed on 12/03/2011)

Correspondence Address:

Dr. Abdul Rehman

Assistant Professor of Paediatrics, Quaid-e-Azam Medical College, Bahawalpur. drarehman100@yahoo.com

Article received on: $\quad$ 05/01/2013 Accepted for Publication: 16/02/2013 Received after proof reading: 00/00/0000 


\section{PREVIOUS RELATED STUDIES}

Dilshad Muhammad, Khalid Amin, Amin Anjum, Masood Javed. CHRONIC HEPATITIS C VIRUS INFECTION; ASSOCIATION WITH TYPE 2 DIABETES MELLITUS (Original) Prof Med Jour 17(4) 557-562 Oct, Nov, Dec 2010.

Waheed Ahmed, Manzar Zakaria, Syed Badshah Hussain Zaidi. HEPATITIS C; FREQUENCY OF THROMBOCYTOPENIA PATIENTS TREATED WITH INTERFERON (Original) Prof Med Jour 17(1) 117-121 Jan, Feb, Mar 2010.

Shaukat Ali, Syed Khurram Shahzad, Atiq ur Rehman Slehria. CHRONIC HEPATITIS C; RESPONSE TO INTERFERON AND RIBAVIRIN COMBINATION (Original) Prof Med Jour 17(4) 563-567 Oct, Nov, Dec 2010.

S. M. Abbas Naqvi, Qurban ali Khaskheli, Shahid Habib Ansari, Muhammad Shiraz Khan, Muhammad Saeed Talpur. HEPATITIS C VIRUS; PREVALENCE IN BLOOD DONORS IN KARACHI (Original) Prof Med Jour 13(4)604-607 Oct, Nov, Dec, 2006.

Nuzhat Parveen Khawaja, Uzma Hussain, Farzana Latif, Rakhshanda Reman. RISK FACTORS FOR HEPATITIS C VIRUS; OBSTETRICS PATIENTS. (Original) Prof Med Jour 16(3) 428-431 Jul, Aug, Sep, 2009.

Muhammad Naeem, Ameer Ahmad, Imran Qaisar, Fiaz Ahmad. STATUS OF HEPATITIS C VIRUS (HCV) INFECTIONS; CHILDREN ADMITTED IN PEDIATRIC WARD OF BAHAWAL VICTORIA HOSPITAL BAHAWALPUR (Original) Prof Med Jour 18(3) 445-449 Jul, Aug, Sep 2011.

Muhammad Joher Amin, M. Haroon Yousuf, Asim Mumtaz, Mr. Ajjad Iqbal, Rashid Ahmed, Saleem-uz-Zaman adbami, Kashif Malik. PREVALENCE OF HEPATITIS B SURE SURFACE ANTIGEN AND ANTI HEPATITIS C VIRUS; AMONG GENERAL POPULATION IN LAHORE (Original) Prof Med Jour 11(3) 334-337 Jul, Aug, Sep, 2004.

Muhammad Afzal, Irfan Ahmed Mughal, Naushen Afzal, Muhammad Badar Bashir, Fiyaz Ahmed Malik. CHRONIC HEPATITIS C INFECTION; CORRELATION OF GLUCOSE TOLERANCE TEST, THE LEVELS OF FASTING BLOOD SUGAR (FBS) AND HEMOGLOBIN (Original) Prof Med Jour 11(2) 222-227 Apr, May, Jun, 2004.

Faqir Muhammad Tariq, Habib Subhani, Irshad Ahmad, Irshad ul Haq. HEPATITIS C; PREVALENCE IN PARAMEDICAL STAFF OF A TEACHING HOSPITAL(Original) Prof Med Jour 16(2) 168-172Apr, May, Jun, 2009.

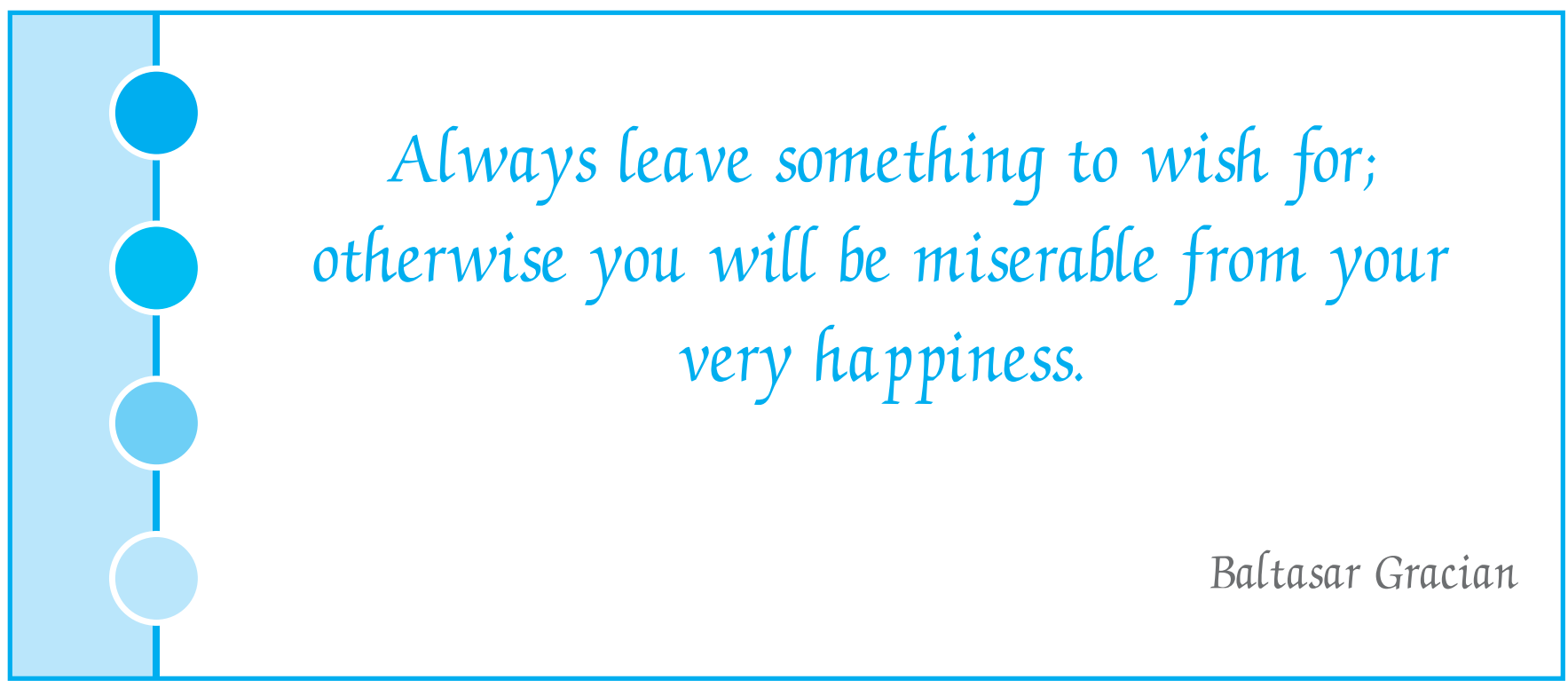

